University of Wollongong

Research Online

Faculty of Law, Humanities and the Arts Papers (Archive)

Faculty of Arts, Social Sciences \& Humanities

$1-1-2014$

The sustainable use and conservation of biodiversity in $\mathrm{ABNJ}$ : What can be achieved using existing international agreements?

Jeff Ardron

Institute forAdvancedSustainabilityStudiese. Berlin

Rosemary Rayfuse

University Of New South Wales

Kristina Gjerde

International Union for Conservation of Nature

Robin Warner

University of Wollongong, rwarner@uow.edu.au

Follow this and additional works at: https://ro.uow.edu.au/lhapapers

Part of the Arts and Humanities Commons, and the Law Commons

Research Online is the open access institutional repository for the University of Wollongong. For further information contact the UOW Library: research-pubs@uow.edu.au 


\title{
The sustainable use and conservation of biodiversity in ABNJ: What can be achieved using existing international agreements?
}

\begin{abstract}
Attention has recently been given to shortcomings and gaps in the governance regime for marine areas beyond national jurisdiction (ABNJ), especially with regard to the conservation of marine biodiversity. This paper provides a brief overview of existing ABNJ treaties and their associated governance bodies.

Examples of the manner in which some gaps have been (or are in the process of being) filled are outlined. These examples suggest that given the political will, existing bodies could achieve significantly more. Additionally, greater involvement from those conservation conventions that have already proven themselves to be effective in areas under national jurisdiction, such as CITES and the World Heritage Convention, could likely be beneficial in ABNJ as well. However, the current arrangement of single-sector institutions poses difficulties when attempting comprehensive measures that require cooperation beyond individual sectors, particularly between sectoral and conservation bodies. Nevertheless, measures that would aid in the protection of biodiversity could, and should, be developed. To ensure their success, the active exploration and testing of new cooperative governance arrangement(s) will be necessary. Methods to inspire sectoral organizations to act may also need to be developed.
\end{abstract}

\section{Keywords}

be, agreements, abnj, can, achieved, existing, sustainable, conservation, international, biodiversity

\section{Disciplines}

Arts and Humanities | Law

\section{Publication Details}

Ardron, J., Rayfuse, R., Gjerde, K. and Warner, R. (2014). The sustainable use and conservation of biodiversity in $\mathrm{ABNJ}$ : What can be achieved using existing international agreements?. Marine Policy, vol.49, pp98-108. 
The sustainable use and conservation of biodiversity in ABNJ: what can be achieved using existing international agreements?

Jeff A. Ardron ${ }^{1 c}$, Rosemary Rayfuse ${ }^{2}$, Kristina Gjerde ${ }^{3}$, Robin Warner ${ }^{4}$

${ }^{1}$ Institute for Advanced Sustainability Studies e.V., Berliner Strasse 130, 14467 Potsdam, Germany. +49 331288 22394; jeff.ardron @iass-potsdam.de

c Corresponding author: +49 33128822 385; jeff.ardron@iass-potsdam.de

${ }^{2}$ Faculty of Law, The University of New South Wales, Sydney, NSW 2052, Australia and Faculty of Law, Lund University, Sweden. r.rayfuse@unsw.edu.au

${ }^{3}$ IUCN Global Marine and Polar Programme and World Commission on Protected Areas; 105 Irving St., Cambridge, MA 02138, kgjerde@eip.com.pl

${ }^{4}$ Australian National Centre for Ocean Resources and Security (ANCORS), Building 233 Innovation Campus, University of Wollongong; rwarner@uow.edu.au

Abstract

Attention has recently been given to shortcomings and gaps in the governance regime for marine areas beyond national jurisdiction $(A B N J)$, especially with regard to the conservation of marine biodiversity. This paper provides a brief overview of existing ABNJ treaties and their associated governance bodies. Examples of the manner in which some gaps have been (or are in the process of being) filled are outlined. These examples suggest that given the political will, existing bodies could achieve significantly more. Additionally, greater involvement from those conservation conventions that have already proven themselves to be effective in areas under national jurisdiction, such as CITES and the World Heritage Convention, could likely be beneficial in ABNJ as well. However, the current arrangement of single-sector institutions poses difficulties when attempting comprehensive measures that require cooperation beyond individual sectors, particularly between sectoral and conservation bodies. Nevertheless, measures that would aid in the protection of biodiversity could, and should, be developed. To ensure their success, the active exploration and testing of new cooperative governance arrangement(s) will be necessary. Methods to inspire sectoral organizations to act may also need to be developed.

Highlights

- Scientific knowledge necessary to protect $A B N J$ is growing

- Bottom fisheries closures now protect some vulnerable marine ecosystems 
- Marine geoengineering is now regulated by international law

- Cooperation between existing agreements is rare, and needs to be improved

- Mechanisms to motivate sectoral organizations to act are required.

1. Introduction

The past decades have witnessed important legal and policy progress towards the better management of expanding human activities and their detrimental effects upon marine ecosystems. However, this progress, which has resulted in the adoption of a wide range of legal and policy instruments and arrangements, is counter-balanced with the sobering news that the ecological success stories remain stubbornly few, particularly in areas beyond national jurisdiction (ABNJ) [1]. ${ }^{1}$ In general, marine biodiversity is under increasing pressures and most indicators show its condition as worsening rather than improving [e.g., 2, 3, 4]. In the ABNJ context, there have been increasing calls for a new global agreement to protect biodiversity in ABNJ (Druel and Gjerde, this issue)[5]. The negotiation of a new agreement should not, however, preclude achieving more through the improved implementation of existing agreements and related instruments [6]. This paper examines options for improving the efficacy of existing agreements, treaty bodies, international organisations and governance processes that are relevant to the protection of biodiversity in ABNJ.

There is a complex legal framework for the governance of ABNJ. In addition to the United Nations Convention on the Law of the Sea (UNCLOS), Table 1 lists the key agreements and institutions relevant to marine resource management and the conservation of biodiversity in ABNJ. These agreements can be sub-divided into two general groupings: 1) sector-specific conventions/treaties for the management of marine resource exploitation and maritime activities and their associated institutions and parties (henceforth the sectoral agreements); and, 2) conservation-oriented conventions/treaties, mandated to conserve species, habitats, and/or ecosystems and their associated institutions and parties (henceforth, the conservation agreements). These international agreements can be further categorised by their geographic scope-either global or regional.

$<$ Insert Table 1 about here>

\footnotetext{
${ }^{1}$ No assessments have looked at fish stocks only in ABNJ, largely due to the unavailability of the data. However, in 2008, the last year that the FAO reported on the status of straddling stocks and other high seas fishes: over $60 \%$ were classed as overfished, depleted or recovering; i.e. twice as many as the currently reported global average.
} 
Table 1. Summary of key agreements and their institutions relevant to marine resource management and the conservation of biodiversity in ABNJ.

\begin{tabular}{|c|c|c|c|c|c|}
\hline Short name & Full name & Year / in force & Parties & Governance / admin. bodies & Comments \\
\hline \multicolumn{6}{|c|}{ Global framework agreement } \\
\hline $\begin{array}{l}\text { UNCLOS } \\
\text { (LOSC) }\end{array}$ & $\begin{array}{l}\text { United Nations Convention on the Law of the Sea } \\
\text { (also known as: Law of the Sea Convention) }\end{array}$ & $1982 / 94$ & $\begin{array}{l}166 \\
\text { (including } \\
\text { the } \\
\text { European } \\
\text { Union -EU) }\end{array}$ & $\begin{array}{l}\text { International Tribunal for the Law of } \\
\text { the Sea / UN Division for Ocean } \\
\text { Affairs and Law of the Sea }\end{array}$ & $\begin{array}{l}\text { For resource management, } \\
\text { UNCLOS is supplemented by two } \\
\text { implementing agreements, below. }\end{array}$ \\
\hline \multicolumn{6}{|c|}{ Global sectoral agreements (primarily to manage marine natural resource exploitation and maritime activities) } \\
\hline $\begin{array}{c}\text { Part XI } \\
\text { Agreement }\end{array}$ & $\begin{array}{l}\text { Agreement relating to the implementation of Part } \\
\text { XI of the United Nations Convention on the Law of } \\
\text { the Sea of } 10 \text { December } 1982\end{array}$ & 1994 / 96 & 145 & $\begin{array}{l}\text { International Seabed Authority } \\
\text { (ISA) }\end{array}$ & $\begin{array}{l}\text { The ISA Council and Assembly } \\
\text { meet annually. }\end{array}$ \\
\hline $\begin{array}{l}\text { Fish Stocks } \\
\text { Agreement }\end{array}$ & $\begin{array}{c}\text { The United Nations Agreement for the } \\
\text { Implementation of the Provisions of the United } \\
\text { Nations Convention on the Law of the Sea of } 10 \\
\text { December } 1982 \text { relating to the Conservation and } \\
\text { Management of Straddling Fish Stocks and Highly } \\
\text { Migratory Fish Stocks }\end{array}$ & $1995 / 01$ & 81 & $\begin{array}{c}\text { Regional fisheries management } \\
\text { organisations/agreements and Flag } \\
\text { States are expected to execute the } \\
\text { agreement. No secretariat per se. }\end{array}$ & $\begin{array}{l}\text { There have been two UN review } \\
\text { conferences (2006 \& 2010). a } \\
\text { Parties need not have ratified } \\
\text { UNCLOS (e.g. the USA). }\end{array}$ \\
\hline $\begin{array}{l}\text { MARPOL and } \\
\text { other } \\
\text { agreements }\end{array}$ & $\begin{array}{c}\text { International Convention for the Prevention of } \\
\text { Pollution from Ships, and other shipping } \\
\text { agreements }\end{array}$ & $\begin{array}{l}1972 \& 78 / 83 \\
\text { (Annex VI } \\
\text { protocol } 1997 \text { / } \\
\text { 05) }\end{array}$ & $74^{b}$ & $\begin{array}{l}\text { International Maritime Organization } \\
\text { (IMO) }\end{array}$ & $\begin{array}{l}\text { There are over } 50 \text { shipping- } \\
\text { related IMO conventions / } \\
\text { agreements. Assembly meets } \\
\text { every } 2 \text { yr. }\end{array}$ \\
\hline LC/LP & $\begin{array}{c}\text { Convention on the Prevention of Marine Pollution } \\
\text { by Dumping of Wastes and Other Matter } \\
1972 \text { and } 1996 \text { Protocol Thereto }\end{array}$ & $\begin{array}{c}1972 / 75 \\
\text { (Protocol } 1996 / \\
06)\end{array}$ & $87-42$ & $\begin{array}{l}\text { Secretariat of the LC/LP is hosted } \\
\text { by the IMO (see above) }\end{array}$ & $\begin{array}{l}\text { Consultative Meeting of the } \\
\text { Contracting Parties is annual. }\end{array}$ \\
\hline IWC & $\begin{array}{l}\text { International Convention for the Regulation of } \\
\text { Whaling }\end{array}$ & $1946 / 48$ & 88 & International Whaling Commission & $\begin{array}{l}\text { In } 1986 \text { a moratorium on } \\
\text { commercial whaling was } \\
\text { established, with some exceptions } \\
\text { for scientific and subsistence } \\
\text { purposes. Meets annually. }\end{array}$ \\
\hline \multicolumn{6}{|c|}{ Global conservation agreements (primarily to protect species, habitats, and/or biodiversity) } \\
\hline CITES & $\begin{array}{l}\text { Convention on International Trade in Endangered } \\
\text { Species of Wild Fauna and Flora }\end{array}$ & $1973 / 75$ & 178 & Autonomous secretariat & $\begin{array}{l}\text { CITES has relatively recently } \\
\text { begun to list marine species -see } \\
\text { text below. Conference of Parties }\end{array}$ \\
\hline
\end{tabular}




\begin{tabular}{|c|c|c|c|c|c|}
\hline & & & & & (COP) every 2-3 yr. \\
\hline CMS & $\begin{array}{l}\text { The Convention on the Conservation of Migratory } \\
\text { Species of Wild Animals }\end{array}$ & 1979 / 83 & 119 & $\begin{array}{c}\text { Secretariat under the UN } \\
\text { Environment Programme (UNEP) }\end{array}$ & $\begin{array}{l}7 \text { binding Agreements, } 5 \text { of which } \\
\text { are marine-related; } 19 \text { voluntary } \\
\text { MOUs, of which } 6 \text { are marine. } \\
\text { COP at least every } 3 \mathrm{yr} \text {. }\end{array}$ \\
\hline CBD & Convention on Biological Diversity & 1992 / 93 & $\begin{array}{l}193 \\
\text { (including } \\
\text { the EU) }\end{array}$ & Secretariat under UNEP & $\begin{array}{l}\text { All UN member states are Parties, } \\
\text { except for the United States, } \\
\text { Andorra, Holy See and South } \\
\text { Sudan. Bi-annual COP. }\end{array}$ \\
\hline$[\mathrm{WHC}]$ & [World Heritage Convention] & $1972 / 75$ & 190 & $\begin{array}{c}\text { Secretariat under the UN } \\
\text { Educational, Scientific and Cultural } \\
\text { Organization (UNESCO) }\end{array}$ & $\begin{array}{l}\text { The WHC is currently not applied } \\
\text { in ABNJ -see text below. }\end{array}$ \\
\hline \multicolumn{6}{|c|}{ Regional agreement bodies (summarised -see Rochette et al this issue) } \\
\hline $\mathrm{RFMO/As}$ & $\begin{array}{l}\text { Regional fisheries management organisations / } \\
\text { agreements }\end{array}$ & various & various & $\begin{array}{l}\text { In ABNJ: } 5 \text { tuna RFMOs (+1 } \\
\text { dolphin agreement). } 9 \text { geographic } \\
\text { RFMOS }^{\dagger}+2 \text { advisory. } 9 \text { Some have } \\
\text { FAO oversight (see comment). }\end{array}$ & $\begin{array}{l}\text { RFMO/As may fall under the UN } \\
\text { Food and Agricultural } \\
\text { Organization's (FAO) } \\
\text { Constitution, or outside the FAO } \\
\text { framework but with FAO } \\
\text { depository functions, or } \\
\text { completely outside FAO's } \\
\text { framework. }\end{array}$ \\
\hline RSAs & Regional Seas Agreements & various & various & $\begin{array}{l}\text { Four currently extend into ABNJ: } \\
\text { Mediterranean (Barcelona } \\
\text { Convention; administered under } \\
\text { UNEP); Northeast Atlantic } \\
\text { (OSPAR, autonomous),South } \\
\text { Pacific (Noumea Convention for } \\
\text { high seas pockets), and Antarctic } \\
\text { (CCAMLR -see below). }\end{array}$ & $\begin{array}{c}\text { Several Regional Seas } \\
\text { Agreements are administered } \\
\text { under UNEP. The Noumea } \\
\text { Convention Article 2(a)(ii) } \\
\text { includes those areas of high seas } \\
\text { which are enclosed from all sides } \\
\text { by the } 200 \text { nm zones of the } \\
\text { parties. }\end{array}$ \\
\hline $\begin{array}{l}\text { CCAMLR / } \\
\text { ATS }\end{array}$ & $\begin{array}{c}\text { Convention for the Conservation of Antarctic } \\
\text { Marine Living Resources / Antarctic Treaty } \\
\text { System }\end{array}$ & $\begin{array}{c}1982 \text { / } 82 ; 1959 / \\
61\end{array}$ & 36 & $\begin{array}{l}\text { The Convention, administered by a } \\
\text { Commission of the same name, is } \\
\text { part of the Antarctic Treaty System. }\end{array}$ & $\begin{array}{l}\text { Often treated as an RFMO it also } \\
\text { has characteristics of an RSA } \\
\text { (see text below). Meets annually. }\end{array}$ \\
\hline
\end{tabular}

${ }^{a}$ Technically, since the first meeting was not closed, the second was a continuation of the first.; i.e. two parts of a single meeting.

${ }^{b}$ The combined merchant fleets of these parties constitute approximately $94.73 \%$ of the gross tonnage of the world's merchant fleet [7]. 
${ }^{\mathrm{c}}$ Cetaceans of the Mediterranean Sea, Black Sea and Contiguous Atlantic Area; Small Cetaceans of the Baltic, North-East Atlantic, Irish and North Seas; Seals in the Wadden Sea; African-Eurasian Migratory Waterbirds; Albatrosses and Petrels.

${ }^{d}$ Marine Turtles of the Atlantic Coast of Africa; Marine Turtles and their Habitats of the Indian Ocean and South-East Asia; Cetaceans and their Habitats of the Pacific Island Region; Dugongs and their Habitats; Eastern Atlantic Populations of the Mediterranean Monk Seal; Small Cetaceans and Manatees of West Africa; Sharks.

${ }^{\mathrm{e}}$ International Commission for the Conservation of Atlantic Tunas (ICCAT), Indian Ocean Tuna Commission (IOTC), Western and Central Pacific Fisheries Commission (WCPFC), Commission for the Conservation of Southern Bluefin Tuna (CCSBT), Inter-American Tropical Tuna Commission (IATTC); Agreement on the International Dolphin Conservation Programme (AIDCP) (associated with IATTC).

${ }^{f}$ North-East Atlantic Fisheries Commission (NEAFC), Northwest Atlantic Fisheries Organization (NAFO), North Atlantic Salmon Conservation Organisation

(NASCO), South-East Atlantic Fisheries Organisation (SEAFO) South Indian Ocean Fisheries Agreement (SIOFA), South Pacific Regional Fisheries Management Organisation (SPRFMO), Convention on Conservation of Antarctic Marine Living Resources (CCAMLR), General Fisheries Commission for the Mediterranean (GFCM), Convention on the Conservation and Management of Pollock Resources in the Central Bering Sea (CCBSP).

${ }^{\mathrm{g}}$ Western Central Atlantic Fisheries Commission (WECAFC), Fisheries Committee for the Eastern Central Atlantic (CECAF). 
The maritime sectoral activities with the greatest potential to affect marine biodiversity in ABNJ, and hence the agreements of interest here, are those concerning fishing (including whaling), shipping (including dumping and placement of wastes at sea), and seabed mining (which is still in the exploratory stage). Mining is overseen by the International Seabed Authority (ISA) based in Kingston, Jamaica; shipping is managed by the International Maritime Organization (IMO), based in London; dumping is regulated through the London Convention and Protocol (LC/LP), the secretariat of which is based in the IMO headquarters in London; and whaling is managed by the International Whaling Commission (IWC), based in Cambridge, United Kingdom. Commercial fisheries are more complex: they are managed by regional fisheries management organizations/agreements (RFMO/As), and where there are no such agreements, by flag states. The Food and Agricultural Organization of the United Nations (FAO), based in Rome adopts some binding and some non-binding fisheries related agreements, serves as secretariat for some (non-regulatory) regional fisheries bodies, and provides advice to all. These sectoral agreements rely mostly upon binding management measures, such as fisheries closures and shipping discharge restrictions. They also utilise voluntary measures such as recommended ships routing and reporting requirements. Compliance can be difficult to ascertain, however, as only some agreements have established compliance mechanisms [8, 9].

Other human activities, such as aquaculture, recreational fishing and tourism, which can be of concern in coastal habitats, are not yet of concern in ABNJ, and space will not permit their consideration here. Submarine cable laying - which does occur in ABNJ - is governed in part by one of the oldest multilateral maritime conventions, the 1884 Convention for the Protection of Submarine Telegraph Cables (in force 1888), which aims to protect cables from damage, mainly from bottom fisheries and anchoring. Potential exists for conflicts between cable laying and other uses as well as potential conservation concerns that may in the future need to be addressed.

With respect to conservation, three global agreements are of particular relevance to $A B N J$ : the Convention on Biological Diversity (CBD); the Convention on the Conservation of Migratory Species of Wild Animals (CMS); and the Convention on International Trade in Endangered Species of Wild Fauna and Flora (CITES), which has recently begun to restrict trade in some marine species. Unlike the sectoral agreements, which have clear legal competencies to establish regulations for their given sectors, the ability of the conservation agreements to develop binding measures varies. The CBD lacks the regulatory authority to adopt binding regulatory measures, applicable within or beyond 
national jurisdiction. ${ }^{2}$ Hence, it relies upon decisions by the Conference of the Parties (COP), targets and guidance to be implemented by its Parties and by other competent organizations. CMS is an umbrella for both binding Agreements and voluntary Memoranda of Understanding (MOUs) for the protection of migratory species and their habitats in the marine environment. However, even in the case of the binding Agreements, CMS like CBD, is limited in its regulatory powers and must rely on its Parties to bring forward appropriate measures to the relevant sectoral agreements. Examples include fisheries related bycatch of marine mammals (covered in binding and non-binding agreements), certain seabirds (binding agreements), turtles (non-binding), or sharks (non-binding). Operationally, the influence of a sub-agreement's legal status is moot, since implementation still requires the crafting and adoption of regulatory measures by sectoral agreements. In this regard, CITES stands apart from $\mathrm{CMS}$ and $\mathrm{CBD}$, in that it has the authority to adopt binding regulations and compliance mechanisms. For this reason its listing of certain commercial fish species has been controversial with those in the fishing community [10]. However, these are species-specific trade measures only, and CITES does not consider other conservation measures such as gear restrictions or protected areas; for these sorts of options, sectoral cooperation is necessary.

At the regional level, the sectoral / conservation agreement sub-division also holds true, with RFMO/As primarily concerned with the management of fisheries, while regional seas agreements (RSAs) are primarily concerned with environmental protection issues such as pollution and the protection of regionally endangered species. As with the global sectoral agreements, with the exception of the two advisory Commissions noted in Table 1, the regional fisheries agreements rely primarily on binding management measures; whereas the regional seas agreements employ a mix of binding and non-binding measures, but lack legal competence to manage or constrain key sectoral activities (i.e. fisheries, shipping, or mining) that may pose a threat to the environment.

The Commission for the Conservation of Antarctic Marine Living Resources (CCAMLR) is treated separately in Table 1 due to its unique mix of management objectives that are characteristic of both a RFMO and a RSA, and the balance it seeks to maintain between fisheries interests, scientific research, and conservation. This mixed mandate has produced some unique fisheries measures, such as a de facto moratorium on bottom trawling [11] -the only region to have done so. However, its consensus-based decision-making means that progress can be blocked on issues opposed by a small minority of parties. This has arguably been evident in CCAMLR's troubled, and to date unsuccessful,

\footnotetext{
${ }^{2}$ Under Article 4 (b), the CBD only applies to the human "processes and activities" under the control of States in $A B N J$, as opposed to protecting the processes and components of biodiversity that reside there. Hence, its legal competence is strictly limited.
} 
process to establish two large marine protected areas (MPAs) for the Ross Sea and East Antarctic [12].

UN bodies without a direct mandate in resource management can play a role in raising awareness and in protecting biodiversity in ABNJ. For example, the United Nations Environment Programme (UNEP) has published on high seas biodiversity issues [13]. The FAO has overseen the negotiation of the legally binding Compliance Agreement [14] and the Port State Measures Agreement [15], as well as developing the voluntary Code of Conduct for Responsible Fisheries and four voluntary 'International Plans of Action' [16].

2. Examples of progress using existing agreements and mechanisms

Despite the number of existing agreements, their effectiveness in protecting biodiversity in ABNJ is open to question. Voluntary measures (commonly used for conservation) have often had limited effect [e.g. 17]. For example, after nearly 14 years, the FAO International Plans of Action have generated minimal engagement. In particular, only 14 countries have submitted management plans for sharks [18], while compliance with these plans remains unknown. Implementation of binding agreements is better, although Parties often fall far short of goals and objectives [e.g., 19, 20]. Despite this patchy record, having an agreement in place, even a voluntary one, is still seen by many as better than no agreement at all as it provides, inter alia, structure and a process to oversee and as necessary, further develop obligations [e.g. 21].

Ample evidence exists of several geographic, sectoral, and governance gaps remaining in ABNJ [e.g., $22,23,24]$. Admittedly, not all of these gaps could be filled using existing agreements / institutions. For example, bioprospecting and subsequent exploitation of marine genetic resources is an issue on which diametrically opposed positions have been taken at the UN. A solution to the management of marine genetic resources in $A B N J$ is therefore unlikely to be found in adapting an existing instrument or agreement [25]. Nevertheless, as discussed in the examples below, there are a number of ways in which existing agreements could fill certain governance gaps.

\subsection{Building regional agreements to fill geographic gaps}

Perhaps the most obvious governance gaps in ABNJ are geographic; i.e. ocean areas where certain types of management and conservation agreements or institutions do not yet exist [26]. In the 
fisheries context, with some notable exceptions, ${ }^{3}$ many of these gaps have been filled since the adoption of the UN Fish Stocks Agreement through the establishment of new RFMO/As. Beyond fisheries, regional agreements with broader conservation-based mandates for ABNJ remain the exception rather than the rule (Table 1). The opportunity therefore exists for the negotiation of new regional agreements for the protection of the marine environment and/or for existing Regional Seas Agreements to expand their conservation-based mandates into ABNJ (Rochette et al, this issue).

\subsection{Adapting to new circumstances: marine geoengineering}

Existing agreements can also potentially adapt to new circumstances. For example, regulation of ocean fertilisation and marine geoengineering, once considered a serious gap, has been addressed by the London Convention and Protocol (LC/LP) and by the CBD. Initially both bodies adopted voluntary measures. However, in 2008, a well-known German research institution co-led an ocean fertilization experiment in the Southern Ocean, in apparent ignorance of the CBD decision that had been passed in Germany just seven months earlier. In 2012, another unauthorised fertilisation 'experiment' took place off the west coast of Canada, involving private interests funded by a Canadian First Nations band. In this second instance, the researchers were not linked to a research institution. This latter event, in particular, appears to have hastened work under LC/LP to adopt stronger, non-voluntary measures.

In October 2013, Contracting Parties LC/LP adopted an amendment to the Protocol concerning marine geoengineering. Only listed marine geoengineering techniques are permitted under the Protocol and only for the purposes of legitimate scientific research as verified by a scientific review procedure [27]. The amendment currently lists only ocean fertilization, however provision is made for the addition of other marine geoengineering methods as they arise [28]. As an amendment, when it enters into force it will be legally binding on parties to the Protocol. This example highlights the flexibility of an existing instrument to expand to encompass new and emerging human activities.

\subsection{CITES: slowly expanding into the marine realm}

\footnotetext{
${ }^{3} \mathrm{~A}$ large gap remains with regard to fisheries in the Southwest Atlantic, where a territorial dispute (re the Malvinas / Falkland Islands) is likely to preclude the establishment of an RFMO for several more years. There is also a gap in the Central Arctic Ocean, Northern Indian Ocean, and another between the North and South Pacific RFMOs on their eastern side. However, apparently little fishing occurs in the ABNJ of these regions -for now, at least.
} 
This flexibility is also apparent in developments under the Convention on International Trade in Endangered Species of Wild Flora and Fauna (CITES). The purpose of CITES is to regulate and in some cases prohibit trade in endangered species. Unlike most conservation agreements, CITES establishes strict reporting requirements and compliance mechanisms. In recent years, CITES has become involved in the protection of endangered marine species of commercial value, including some species of sea horses, corals, eels, and sharks. Nevertheless, as the opposition to the proposed listings of Bluefin Tuna and various shark species demonstrates, states engaged in those fisheries consider such listings to be inappropriate and have opposed CITES listing on the basis that the regulation of fisheries should remain the exclusive domain of existing fisheries agreements. On the other hand, it has been argued that adding a global trade component would support the regional decisions of the RFMO/As, and hence the invocation of CITES could be mutually beneficial for fisheries management [29].

Notwithstanding the reluctance of some states, CITES is unique in its role as an international multilateral agreement that seeks to address conservation through trade measures. The conservation of marine biodiversity in ABNJ, as indeed within national jurisdiction, is a complex problem requiring multi-dimensional solutions. With its broad support, ${ }^{4}$ extensive Appendices, and long history of implementation and compliance, the potential future role of CITES in the sustainable use and conservation of biodiversity in ABNJ should not be discounted.

\subsection{World Heritage designations in ABNJ?}

Another global agreement which could potentially be applied to ABNJ is the 1972 World Heritage Convention. The Convention represents a well-established vehicle for protecting places of Outstanding Universal Value. Although its application has, to date, been limited to land and national waters, there is growing interest in considering how its coverage could be expanded. ${ }^{5}$ In 2011, the $18^{\text {th }}$ General Assembly of States Parties to the World Heritage Convention endorsed the audit of the Convention's global strategy, Recommendation Five of which called upon the parties to: "reflect upon appropriate means to preserve sites that correspond to conditions of outstanding universal value, which are not dependent on the sovereignty of States Parties" [30]. Nothing in the Convention restricts its possible application to ABNJ. Thus it is open to the parties to develop relevant procedures and management and compliance mechanisms. Certainly, a number of issues would need to be resolved such as identification and possible establishment of a responsible body

\footnotetext{
${ }^{4}$ There are 177 Parties, representing about $90 \%$ of the world's countries.

${ }^{5}$ This was the topic of an expert advisory group meeting, 18-19 March 2013, supported by UNESCO World Heritage Programme, hosted by IASS, in Potsdam, Germany, and attended by some of the authors.
} 
for developing management plans and monitoring compliance, and the range of measures available to address non-compliance. These hurdles need not, however, be seen as insurmountable.

\subsection{The CBD EBSA process}

In 2005 the CBD launched its EBSA process (described more fully in Dunn et al, this issue) designed to identify ecologically or biologically significant areas in ABNJ (and also under national jurisdiction when invited to do so). In 2008, the CBD COP adopted criteria for the identification of EBSAs [31] and, after a series of regional workshops, the first group of 48 EBSAs was considered at CBD COP 11 in October 2012. At the request of the COP a letter was sent by the Secretariat to the UNGA on 19 March 2013 introducing the EBSAs. This was distributed to state parties by the UN on 17 April 2013 [32]. By systematically describing ecologically important places in most parts of the global ocean the CBD EBSA process has aided regional capacity building and cooperation and has added significantly to the knowledge base upon which conservation efforts can proceed. In this respect it demonstrates that an existing conservation agreement, within its limited powers, can nevertheless contribute to the conservation of global marine biodiversity.

The CBD has also been active in other ways. It has elaborated guidelines for biodiversity-inclusive environmental impact assessments and strategic environmental assessments specifically for marine areas, including ABNJ. In 2010, the COP adopted twenty Aichi Biodiversity Targets, two of which are particularly relevant to marine conservation. Target 6 seeks to seeks to establish sustainable fisheries by 2020 , and Target 11 seeks to protect at least $10 \%$ of coast and marine areas (including ABNJ) by 2020 [33]. (This new target replaced the previous (unfulfilled) CBD MPA target of 10\% by 2012 [34].) Although the CBD COP has agreed to specific MPA and fisheries targets, as noted above the CBD lacks the regulatory authority to directly implement them, either within or beyond national jurisdiction. Rather, it relies on compliance through the actions of its Parties nationally and, in ABNJ, through their actions as flag states and their participation in the sectoral agreements.

\subsection{The United Nations processes}

The UN has played an increasing role as a forum for global oceans issues, hosting a number of oceanrelated processes, including a periodic review of the Fish Stocks Agreement, the annual Open-ended Informal Consultative Process on Oceans and the Law of the Sea, and annual negotiations of the Sustainable Fisheries and omnibus Oceans and Law of the Sea resolutions. Additionally, it has passed specific resolutions aimed at protecting marine species and habitats, and has launched a 
process to study issues related to the conservation and sustainable use of biodiversity in ABNJ, discussed below.

\subsubsection{UNGA resolutions}

While UN General Assembly (UNGA) resolutions are considered to be 'soft law' (voluntary) [35], when properly formulated they can, in practice, be very compelling, as evidenced by the indefinite moratorium on large scale drift net fishing adopted by UNGA Resolutions in 1990-1992 [36].

More recently, in 2006 the UNGA passed resolution 61/105 (and in 2009, 64/72) calling upon States and RFMO/As with the competence to regulate bottom fisheries to adopt and implement four key measures, including closures to protect vulnerable marine ecosystems (VMEs) [37]. The importance of these UNGA deep sea bottom fishing resolutions should not be under-estimated; despite some inconsistencies and flaws in implementation (briefly outlined below), they have nevertheless sparked the establishment of new RFMOs and have triggered several fisheries closures, many of them in regions where no closures had ever previously existed. These resolutions may also have played a significant role in the updating of the mandates of and measures adopted by a number of RFMOs, including the two in the North Atlantic. An important reason for the apparent success of this approach lies in the procedures adopted. The 2006 resolution set out a clear time line requiring a UNGA review of progress in 2009, which then resulted in a second review in 2011.

However, even with a clearly stated timeline, the 2011 UN review found that while some progress had been made, many further actions were required [38]. These findings reflected to a large degree what environmental non-governmental organisations (NGOs) [39] and also scientists [40] had been saying in separate reports; i.e. that the threat from bottom fishing to deep sea ecosystems, although reduced, still remains significant. Problems in the implementation of these measures have included problems in 'freezing of the fishing footprint' [41], the selection of areas to be closed, and how best to engage the fishing industry. The importance of stakeholder engagement in ensuring compliance is well recognised [42]. However, an overly influential role for the offshore deep sea bottom fishing industry has arguably led to some poor conservation decisions, protecting areas of little interest from both a fishing and a conservation standpoint but failing to protect areas of both conservation and fishing interest [43]. Hence, a more balanced approach to implementation, which incorporates the provision of peer-reviewed science and transparent reporting procedures, is needed. 'Good practices' regarding the identification and protection of vulnerable marine ecosystems (VMEs) are 
now emerging (Ardron et al, this issue) and the lessons learnt might also be valuably applied elsewhere, such as in the protection of the EBSAs, discussed above [44].

\subsubsection{BBNJ}

Recognising the need to better protect biodiversity in ABNJ, the UNGA decided in 2004 to establish the Ad Hoc Open-ended Informal Working Group to Study Issues Relating to the Conservation and Sustainable use of Marine Biological Diversity beyond Areas of National Jurisdiction (BBNJ) [45]. BBNJ first met in 2006, where the delegations noted that "...existing mechanisms and institutions needed to apply a multi-sectoral and integrated approach to management and cooperate and coordinate to that end, thus moving away from their current sectoral approach" [46]. At subsequent BBNJ meetings there has been continued agreement that more could be achieved through better cooperation, coordination and implementation of existing global and regional arrangements. As noted in the Co-Chairs' Summary of Discussion from the fifth meeting of BBNJ, in 2012:

...an assessment of possible ways and means of achieving more effective coordination and implementation of sectoral management regimes in the fields of fisheries, seabed mining and shipping would be essential. It was suggested that the Working Group [BBNJ] could consider such mechanisms for achieving coordinated implementation of ecosystem approaches by sectoral bodies and States, including through tools such as marine protected areas and environmental impact assessments [47].

This passage highlights the three key human activities -fisheries, shipping, mining- as well as two key management tools where coordination would be advantageous - marine protected areas (MPAs) and environmental impact assessments (EIAs). The explicit mention of "mechanisms for achieving coordinated implementation" potentially moves the discussion beyond routinely encouraging cooperation, as per the yearly UNGA omnibus ocean resolution, towards the development of a mechanism to do so. However, as with the summary of the first BBNJ meeting in 2006, while it emphasises the value of cooperation and coordination, there is still no proposal for how this might be achieved.

At the most recent BBNJ meeting in August 2013, states agreed to a process to consider the "scope, parameters and feasibility" of a new international instrument under UNCLOS for conservation and sustainable use of marine biodiversity beyond national jurisdiction. Consideration of these elements is to contribute to a decision by August 2015 on whether to proceed with a new instrument under 
the UNCLOS or not (Druel \& Gjerde, this issue). Due to the focus on a potential new instrument, alternative approaches to improving cooperation and coordination using existing instruments for the protection of biodiversity have, for now at least, fallen off the agenda. Instead, key States have agreed to a so-called package approach (Druel \& Gjerde, this issue). Until progress is made on the other issues in the package, including questions related to benefit sharing of marine genetic resources from $A B N J$, and capacity building and transfer of technology, there will likely be reluctance at BBNJ to proceed on issues related to marine conservation.

\section{Spatial protection using existing instruments}

Given the slow and uncertain progress of the UN discussions, other avenues for the protection of biodiversity in ABNJ should be considered.

As captured in the commitments made by States at the United Nations 'Earth Summits' (Rio 1992, Johannesburg, 2002 [48] and Rio 2012 [49]), and in CBD Aichi Target 11 (discussed above), broad recognition exists of the value of area-based management tools including MPAs. Admittedly, MPAs are just one of several management tools. However, given that less than half a percent of ABNJ is protected through MPAs [51], they have become something of a touchstone for those in the ABNJ debates as a significant indication of governance short-comings.

Legally, an ecosystem-based approach including a representative system of comprehensive MPAs that protect a full range of species and habitats, falls outside the scope of any single agreement [50]. Sectoral agreements, by definition, apply only to sectoral activities. Conservation agreements, though possessing broader mandates, lack the powers necessary to regulate the major anthropogenic threats. The advantages of a new Implementing Agreement under UNCLOS to meet existing global commitments for integrated and precautionary management in ABNJ have been well articulated elsewhere [51] (Druel and Gjerde, this issue). In the absence of such agreement, however, the potential for more area-based management using existing agreements is worth exploring.

Table 2 summarises the existing area-based management tools available in ABNJ. As Table 2 indicates, no single agreement has the mandate to establish comprehensive networks of MPAs. Half of the listed agreements have applicable tools, while half do not. This suggests both an opportunity for further application of existing agreements, as well as a need to expand the mandates of others to include the availability and application of spatial protection measures. 
$<$ Insert Table 2 about here>

Table 2. Area-based management tools that are specified by international agreements or their implementing bodies.

\begin{tabular}{|c|c|c|}
\hline $\begin{array}{l}\text { Short name (full } \\
\text { names in Table 1) }\end{array}$ & Area-based tools in ABNJ & Comments \\
\hline UNCLOS & none & $\begin{array}{l}\text { Provides the legal framework for the sectoral and } \\
\text { conservation agreements below. Requires the protection } \\
\text { of rare and fragile ecosystems and the habitats of } \\
\text { depleted, threatened or endangered species (Article } \\
\text { 194.5) but no specific provisions. }\end{array}$ \\
\hline \multicolumn{3}{|c|}{ Global sectoral agreements } \\
\hline $\begin{array}{l}\text { Part XI Agreement } \\
\qquad(\text { ISA) }\end{array}$ & $\begin{array}{l}\text { Areas of Particular Environmental } \\
\text { Interest (APEI), Preservation } \\
\text { reference zones [52] }\end{array}$ & $\begin{array}{l}9 \text { APEls in the North Central Pacific (Clarion-Clipperton } \\
\text { Zone) [53] }\end{array}$ \\
\hline $\begin{array}{l}\text { Fish Stocks } \\
\text { Agreement }\end{array}$ & none & $\begin{array}{l}\text { Requires the protection of biodiversity in the marine } \\
\text { environment (article } 5(\mathrm{~g}) \text { but no specific provisions. } \\
\text { Closed areas are briefly mentioned but not specified in } \\
\qquad \$ 11(\mathrm{c}) \text {. }\end{array}$ \\
\hline $\begin{array}{l}\text { MARPOL and other } \\
\text { shipping } \\
\text { agreements (IMO) }\end{array}$ & $\begin{array}{c}\text { Special Areas (SAs) [MARPOL; 54], } \\
\text { Particularly Sensitive Sea Areas } \\
\text { (PSSAs) [IMO; 55], Areas To Be } \\
\text { Avoided (ATBAs) [SOLAS; 56] }\end{array}$ & $\begin{array}{l}2 \text { SAs in ABNJ (Mediterranean and Antarctic). Ship } \\
\text { routing measures could also be considered as a tool. }\end{array}$ \\
\hline LC/LP & none & $\begin{array}{c}\text { While permitting / approval of activities and projects can } \\
\text { have a spatial component, there is no protected area } \\
\text { designation per se. }\end{array}$ \\
\hline IWC & Sanctuaries & $\begin{array}{l}\text { Two established: Indian Ocean (1979) and Southern } \\
\text { Ocean (1994) }\end{array}$ \\
\hline Glob & servation agreements (primarily to & orotect species, habitats, and/or biodiversity) \\
\hline CITES & none & CITES focusses on trade. \\
\hline CMS & none & $\begin{array}{l}\text { Requires the protection of habitats and removal of } \\
\text { obstacles to migration. CMS has mostly focussed on } \\
\text { national jurisdiction, where Range States are expected to } \\
\text { cooperatively develop such measures. }\end{array}$ \\
\hline CBD & none & While CBD actively encourages the establishment of \\
\hline
\end{tabular}




\begin{tabular}{|c|c|c|}
\hline & & protected areas, it lacks the authority to do so itself. \\
\hline$[\mathrm{WHC}]$ & [World Heritage sites] & WHC currently not applied in ABNJ \\
\hline \multicolumn{3}{|c|}{ Regional agreement bodies } \\
\hline RFMO/As & fisheries closures & $\begin{array}{l}\text { In response to the UNGA bottom fishing resolutions, } \\
\text { there are several closures in place to protect VMEs. }\end{array}$ \\
\hline RSAs & MPAs & $\begin{array}{c}7 \text { MPAs in ABNJ under OSPAR (NE Atlantic) and } 1 \text { under } \\
\text { the Barcelona Convention (Mediterranean) }\end{array}$ \\
\hline CCAMLR / ATS & $\begin{array}{c}\text { MPAs [57], fisheries closures, } \\
\text { Antarctic Specially Protected Areas } \\
\text { and Antarctic Specially Managed } \\
\text { Areas (ASPAs, ASMAs) [58] }\end{array}$ & $\begin{array}{c}1 \text { offshore MPA, annual fisheries closures, and several } \\
\text { coastal ASMAs/ASPAs with a marine component } \\
\text { (technically ABNJ) }\end{array}$ \\
\hline
\end{tabular}

\subsection{From singular protections to integrated networks}

Given that more can be done on a sector-by-sector basis, it nevertheless remains to be determined how such designations could collectively contribute to an integrated, representative, and comprehensive network of MPAs. When considering MPA networks in ABNJ, it is worth first looking at what has been achieved in national waters, where conservation efforts have had several decades to mature. Surprisingly, despite many national objectives being set, and the urgency of the issues, nowhere has a coherent network of protected areas yet been designated-except perhaps recently in Australia, amidst controversy coming from scientists and stakeholders on both sides of the debate $[59,60,61]$.

While national networks of MPAs have not yet fully met network-level goals such as representativity, replication, connectivity, and adequacy/viability [62], the individual MPAs that have been established within national jurisdictions have often proven to be very effective at rebuilding abundances of local populations of exploited fishes and other species ${ }^{6}$ [63]. Extrapolating to ABNJ, it is arguable that a site-based or sector-by-sector approach that selects areas based on their ecological or biological significance, using for example, the criteria and information developed by the CBD, could be a good place to start. In practice, the approach within national jurisdictions has been to proceed incrementally, first protecting a few key (often well-known) areas, and then progressively filling in gaps to move toward the goal of representativity. Admittedly this incremental approach is contrary to the objectives of systematic and complementary network planning [64]. However, it is unlikely that all ecologically important sites in ABNJ can be protected at once. Scheduled

\footnotetext{
${ }^{6}$ There have been hundreds of MPA analyses and several meta-analyses with similar results. For a listing of these meta-analyses (i.e. a meta-meta-analysis), see Huntington (2011) [63].
} 
prioritisations, considering sites most critical to biodiversity (i.e. irreplaceable), and also under threat (i.e. vulnerable) is one pragmatic approach that has been used on land $[65,66]$. A similar approach in ABNJ could be initiated using sector-specific area-based protection measures, considering critical sites most at risk from the sector's activities. Though just one aspect of MPA network design, ${ }^{7}$ which alone would not meet internationally accepted commitments or objectives, it would at least be a worthy beginning.

\section{Cooperation}

The above discussion on spatial protection highlights the necessity of cooperation amongst agreements (and their Parties) in order to properly protect marine biodiversity in ABNJ. As noted above, states have cooperated in the adoption of a plethora of agreements relevant to the protection of marine biodiversity in ABNJ. However, the governance bodies established by these agreements have largely kept to themselves, developing their own particular culture, vernacular, and ways of framing issues. The value of cooperation between and among treaty and other bodies is to some extent recognised, and some progress has been made. For example, the six RFMOs that manage tunas have met three times since 2007, as have the Regional Fishery Body Secretariats Network, which includes all active RFMO/As. Representatives to Regional Seas Conventions and Action Plans have, as of 2013, met 15 times. The Conservation agreements, CITES and CMS, have also been establishing inter-agreement cooperative mechanisms. However, cooperation that extends beyond like-minded institutions is rare. (See Freestone et al this issue for examples of two ongoing efforts to secure such cooperation.) From a pragmatic perspective, the development of specialised agreements and governance arrangements to manage sector-specific activities makes sense. When it comes to the establishment of conservation measures designed to protect a broad range of species and habitats, however, an ecosystem approach is widely recommended; indeed, required by international law. This approach, which is incorporated in a range of related treaties and was adopted by the Parties to the CBD in 2000 [67], requires looking at the (potential) impacts of human activities as a whole.

\subsection{Cooperation as a legal duty}

More than a valuable approach, cooperation is a legal duty. The duty of states to cooperate in the conservation and management of living resources in the areas of the high seas is clearly articulated in

\footnotetext{
${ }^{7} \mathrm{CBD}$ decision IX/20 annex 2, has five criteria of which only the first is EBSAs.
} 
Articles 117 and 118 of UNCLOS. ${ }^{8}$ Similarly, Article 5 of the CBD calls for cooperation in ABNJ on the conservation and sustainable use of biodiversity. The status of the duty as a rule of customary international law binding on all states is now generally accepted [68]. However, the precise parameters and extent of the obligation remain unclear, making its implementation less than thorough. Nevertheless, it is suggested here that significant scope exists for increased cooperation not only between states but between and among the international agreements and governance bodies they have established.

\subsection{Cooperation among 'siloes'}

As noted above, since the conservation agreements do not have direct competence in the management of maritime activities they must rely on the sectoral agreements for implementation of their mandates through regulation of activities that may pose a threat to biodiversity as a whole. Therefore, from the perspective of the conservation agreements, in order to meet their ecosystembased objectives, cooperation with the sectoral agreements is seen as advantageous and necessary. However, from the perspective of the sectoral agreements, the advantages of cooperating with conservation agreements are perhaps less pressing or apparent.

For parties to sectoral agreements to better appreciate the value of such cooperation, three preconditions would likely have to be met: 1) broad acceptance by the sectoral agreements that there is a need for and potential benefits for the respective sectors in further conservation actions [69]; 2) recognition of the duty in their underlying legal agreements to cooperate in the coordination of measures with other sectoral agreements; and 3) recognition of a duty to cooperate in the development of measures necessary for the protection and preservation of marine living resources with those bodies that have such expertise. It should be self-evident that international conservation agreements offer considerable expertise in this regard.

The CBD has been proactive in efforts to convene experts in biodiversity and fisheries to discuss topics of common concern. In December 2011, the CBD Secretariat convened a joint expert meeting to review the extent to which biodiversity concerns are addressed in existing assessments of fisheries stocks and to propose options to address biodiversity concerns [70]. This meeting brought together representatives of RFMOs, the Fisheries Expert Group of the International Union for Conservation of Nature's Commission on Ecosystem Management and other relevant organizations, processes and

\footnotetext{
${ }^{8}$ Cooperation is also expressed in several other articles of UNCLOS, including Article 197, stipulating a general duty to cooperate internationally and regionally for the protection and preservation of the marine environment.
} 
scientific groups. The meeting report noted that successive ICES expert reviews have found that there is fairly full attention to the major biodiversity considerations in the RFMO conventions and overarching high level policies but implementation is often highly variable and inadequate [71]. In some cases, the priority that fisheries management agencies could give to the biodiversity commitments in RFMO conventions and policies was constrained by these documents giving explicit primacy to single species Maximum Sustainable Yield (MSY) goals or other harvest goals for the single species [72]. The reviews also found that limits on knowledge of ecosystems and the fisheries and on capacities for assessments and management can impede the achievement of high level biodiversity goals [73].

\subsection{Vested interests impeding cooperation?}

Another problem plaguing cooperation in ABNJ arises from the often tenuous distinction between regulator and regulated and the existence of vested interests. At the meetings of the sectoral agreements, states that participate in decision-making are also very often the direct or indirect beneficiaries of these decisions. For example, regional fisheries bodies are run almost exclusively ${ }^{9}$ by states with an active interest in the fisheries for that region. Thus, in fishing quota negotiations states typically determine allocations which benefit companies, nationals, and vessels under their flags. With regard to shipping, those flag states with a larger stake in the industry (i.e. more registered tonnage) have greater say in decision-making affecting the industry. ${ }^{10}$

Similarly, under UNCLOS and its Part XI Implementing Agreement, the seabed beyond national jurisdiction (the Area) is legally regarded as the common heritage of mankind and seabed mining is subject to the establishment of a benefit-sharing mechanism. Thus, in the ISA there is a broad expectation that mining profits will be shared. Hence there is also an incentive towards approving mining requests, since all Parties stand to gain. Admittedly, to date, decisions have related solely to exploration leases. Approval of commercial exploitation has yet to occur and the details of a benefitsharing mechanism have yet to be determined. Significant work has already taken place to delineate

\footnotetext{
${ }^{9}$ With the exception of CCAMLR and IWC, both of which also include States that do not have interests in exploiting the resources. However CCAMLR passes all decisions by consensus, thereby giving fishing nations the power of veto.

${ }^{10}$ IMO's Council is comprised as follows: Category (a), 10 States with the largest interest in providing international shipping services; Category (b), 10 other States with the largest interest in international seaborne trade; Category (c), 20 States not elected under (a) or (b) above which have special interests in maritime transport or navigation, and whose election to the Council will ensure the representation of all major geographic areas of the world. (http://www.imo.org/About/Pages/Structure.aspx)
} 
environmental responsibilities of States and their authorized Contractors. Nevertheless, the spectre of the adverse impact of vested interests on the decisions taken within the ISA is real.

\section{Discussion}

As noted above, considerable scope exists for the institutions already in place for managing fisheries, shipping, and seabed mining to be more proactive in addressing the most pressing of the current direct human threats to biodiversity in ABNJ. Continued delay serves only to buy time for those who seek to profit from the unsustainable use of the resources [74, 75]. Pending the adoption of a comprehensive global legal framework to designate ecologically coherent, representative networks of MPAs in ABNJ, experience from national jurisdictions suggests that the creation of protected area networks could at least be contributed to by focusing on significant areas first and then seeking to fill the representativity holes later. Without implying support for complacency, if meeting the MPA (and similar) commitments is viewed as a collective process requiring a variety of regional and global instruments working towards a shared goal (e.g. 10\% protected areas), then arguably any step taken towards that goal using whatever tools are at our disposal should be seen as legitimate and useful. The same logic applies to other measures such as environmental impact assessments, where singlesector measures are a necessary beginning. However, ultimately only cross-sectoral cooperation that addresses multiple species, habitats, and cumulative impacts, will provide the means to fully achieve conservation objectives.

Significantly, while the CBD EBSA process has been impressive in its scope and ambition, the question remains how to encourage the sectoral agreements to incorporate EBSAs into their planning and decision-making. The distribution of a letter between Secretariats is unlikely to be sufficient. EBSAs, like all conservation initiatives in ABNJ, will need strong State 'champions' if they are to become accepted outside of the CBD. Moreover, as discovered by the OSPAR Commission in its ongoing efforts to develop cooperative management plans for its high seas MPAs, attempting cross and intersectoral cooperation can add considerably to a secretariat's workload (Freestone et al, this issue). Mechanisms to manage this workload increase would facilitate future progress. In addition, while secretariats can deliver messages back and forth to their respective COPs, greater cooperation would likely require the Parties themselves to come together; e.g. in a special joint-meeting or COP, or to adopt a joint programme or plan of action, or designate a joint science advisory body or process. Given the obvious synergies and economies of scale to be gained by joining forces and sharing expertise across the conservation-sectoral divide, these possibilities are worth further examination. A 
common global mandate from a UNGA resolution (or indeed a new global agreement), accompanied by funding to incentivize cooperation, would stimulate progress.

To date, cooperation has shown itself to be the Achilles heel of the existing constellation of agreements. Currently, a proposal originating in a conservation agreement must find a government that is also a member of a sectoral agreement willing to shepherd it through the intricacies of the sectoral agreement's regulatory approval process. Thus, even though many governments may support a given conservation measure, finding one willing to champion it can be difficult. A better procedure, which would build cooperation, might be one that allowed for a secretariat from one agreement body to officially submit proposals to another.

In any event, for those who argue that the existing agreements are alone sufficient to achieve the protection of biodiversity, they will have to better demonstrate how inter-agreement cooperation can be achieved. As mentioned above, the CBD has investigated cooperation between RFMOs and conservation organisations and has made a number of recommendations, as yet unimplemented, as to how cooperation might be improved [76]. Further guidance might also be gleaned from studying the recent experience of the merger of the Secretariats of the Basel, Stockholm and Rotterdam Conventions. Whatever approaches are taken, however, it is clear that the greater use of existing mechanisms is not itself a panacea or a quick fix. Rather it represents a sensible approach to making the most of existing arrangements without in any way foreclosing the possibility of the adoption of a better, more comprehensive, integrated approach to the protection of marine biodiversity in ABNJ.

\section{Acknowledgements}

This paper arose out of a workshop held March 2013 at the Institute of Advanced Sustainability Studies, Potsdam, Germany; thanks in particular to the participants of the Working Group on Existing Instruments for the thoughtful discussion.

\section{References}

[1] Food and Agriculture Organization of the United Nations. The state of world fisheries and aquaculture, 2008 \& 2012. Rome, Italy.

[2] Millennium Ecosystem Assessment. Ecosystems and Human Well-being: Biodiversity Synthesis. World Resources Institute, Washington, DC, 2005.

$<$ http://www.millenniumassessment.org/documents/document.354.aspx.pdf $>$ [Accessed Sept. 2013].

[3] Secretariat of the CBD Global Biodiversity Outlook 3. 2010.

[4] Rogers A, Laffoley D. Introduction to the special issue: The global state of the ocean; interactions between stresses, impacts and some potential solutions. Synthesis papers from the International Programme on the 
State of the Ocean 2011 and 2012 workshops, Marine Pollution Bulletin, in press.

http://www.stateoftheocean.org/pdfs/Rogers-Laffoley-2013.pdf Accessed Sept. 2013.

[5] Gjerde K, Rulska-Domino A. Marine Protected Areas beyond National Jurisdiction: Some Practical

Perspectives for Moving Ahead. The International Journal of Marine and Coastal Law 2012,27:351-373.

[6] Ardron J, Druel E, Gjerde K, Houghton K, Rochette J, Unger S. Advancing High Seas Governance. IASS Policy brief $1 / 2013$.

[7] International Maritime Organization. Status of multilateral Conventions and instruments in respect of which the International Maritime Organization or its Secretary-General performs depositary or other functions, as at 18 November 2013. <http://www.imo.org/About/Conventions/StatusOfConventions/Documents/Status\%20\%202013.pdf > [Accessed Nov 2013].

[8] Koehler H. Promoting Compliance in Tuna RFMOS: A Comprehensive Baseline Survey of the Current Mechanics of Reviewing, Assessing and Addressing Compliance with RFMO Obligations and Measures. International Seafood Sustainability Foundation, USA. ISSF Technical Report 2013-02.

[9] Gilman E, Kingma E. Standard for assessing transparency in information on compliance with obligations of regional fisheries management organizations: Validation through assessment of the Western and Central Pacific Fisheries Commission. Ocean \& Coastal Management 2013, 84:31-39.

[10] CITES. Press release: conference takes decisive action to halt decline of tropical timber, sharks, manta rays and a wide range of other plants and animals. 2013.

<http://www.cites.org/eng/news/pr/2013/20130314 cop16.php> [Accessed Sept. 2013].

[11] Commission for the Conservation of Antarctic Marine Living Resources. Restrictions on the use of bottom trawling gear in high-seas areas of the Convention Area, 2008. Conservation Measure 22-05.

[12] Center for American Progress. Russia Blocks Bid to Establish Massive Antarctic Marine Reserves. 18 July 2013. <http://www.americanprogress.org/issues/green/news/2013/07/18/70015/russia-blocks-bid-toestablish-massive-antarctic-marine-reserves/> [Accessed Nov 2013].

[13] United Nations Environment Programme. Ecosystems and Biodiversity in Deep Waters and High Seas. UNEP Regional Seas Reports and Studies, 2006; No. 178. UNEP/ IUCN, Switzerland.

[14] The Agreement to Promote Compliance with International Conservation and Management Measures by Fishing Vessels on the High Seas, 1993 (in force 2003).

[15] Agreement on Port State Measures to Prevent, Deter and Eliminate Illegal, Unreported and Unregulated fishing, 2009 (not yet in force).

[16] Food and Agricultural Organization of the United Nations. Code of Conduct for Responsible Fisheries, 1995; International Plan of Action for Reducing Incidental Catch of Seabirds in Longline Fisheries, 1999; International Plan of Action for Conservation and Management of Sharks, 1999; International Plan of Action for the Management of Fishing Capacity, 1999; International Plan of Action to Prevent, Deter and Eliminate Illegal, Unreported and Unregulated Fishing, 2001.

[17] FAO. Progress in implementing the provisions of the code of conduct for responsible fisheries (CCRF) relevant to aquaculture and culture-based fisheries. COFI:AQ/II/2003/4.

[18] FAO, International plan of action for the conservation and management of sharks.

<http://www.fao.org/fishery/ipoa-sharks/npoa/en> [Accessed Nov 2013].

[19] Cullis-Suzuki S, Pauly D. Failing the high seas:A global evaluation of regional fisheries management organizations. Marine Policy 2010, 34:1036-1042.

[20] Perkins R, Neumayer E. Implementing multilateral environmental agreements: an analysis of EU directives. Global Environmental Politics. 2007, 7(3):13-41.

[21] Techera EJ \& Klein N. Fragmented governance: Reconciling legal strategies for shark conservation and management. Marine Policy 2011, 35(1):73-78.

[22] Gjerde KM et al. Regulatory and Governance Gaps in the International Regime for the Conservation and Sustainable Use of Marine Biodiversity in Areas beyond National Jurisdiction. 2008. IUCN, Gland, Switzerland. [23] Drankier P. Marine protected areas in areas beyond national jurisdiction. The International Journal of Marine and Coastal Law 2012, 27:351-373.

[24] Gjerde KM \&Rulska-Domino A. Marine Protected Areas beyond National Jurisdiction: Some Practical Perspectives for Moving Ahead. The International Journal of Marine and Coastal Law 2012, 27: 291-350. [25] Druel E, Rochette J, Billé R, Chiarolla C. A long and winding road. International discussions on the governance of marine biodiversity in areas beyond national jurisdiction. IDDRI, studies no. 07/2013. 2013. < http://www.iddri.org/Publications/A-long-and-winding-road> [Accessed Aug. 2013].

[26] Ban NC, Bax NJ, Gjerde KM, Devillers R, Dunn DC, Dunstan PK, Hobday AJ, Maxwell SM, Kaplan DM, Pressey RL, Ardron JA, Game ET, Halpin PT. Systematic conservation planning: A better recipe for managing the high 
seas for biodiversity conservation and sustainable use. Conservation Letters, 2013: 00 (advance web publication).

[27] Verlaan P. Current Legal Developments. London Convention and London Protocol. International Journal of Marine and Coastal Law 2013,28(4)729-236.

[28] London Convention and Protocol. Report of the Working Group on the Proposed Amendment to the London Protocol to Regulate Placement of Matter for Ocean fertilization and other Marine Geo-engineering Activities, 17 October 2013,LC Doc 35/WP.3.

[29] Vincent, A.C.J, Y.J. Sadovy. S.L. Fowler \& S. Lieberman. In press. The role of CITES in the conservation of marine fishes subject to international trade. Fish and Fisheries in press. published online 10 June 2013, <http://onlinelibrary.wiley.com/doi/10.1111/faf.12035/abstract > [Accessed Dec. 2013].

[30] UNESCO. Final report of the Audit of the Global Strategy and the PACT initiative. 2011, WHC-

11/35.COM/INF.9A; page 24. http://whc.unesco.org/archive/2011/whc11-35com-INF9Ae.pdf

[31] CBD, 2008; Decision IX/21 (Annex1).

[32] United Nations General Assembly. Letter dated 19 March 2013 from the Executive Secretary of the CBD addressed to the Secretary-General. 2013; A/67/838.

[33] CBD. Framework for monitoring implementation of the achievement of the 2010 target and integration of targets into the thematic programmes of work. 2006; COP 8 Decision VIII/15; Annex II. <

http://www.cbd.int/decision/cop/default.shtml?id=11029> [Accessed Nov. 2013].

[34] CBD. Framework for monitoring implementation of the achievement of the 2010 target and integration of targets into the thematic programmes of work. 2006; COP 8 Decision VIII/15; Annex II. <

http://www.cbd.int/decision/cop/default.shtml?id=11029> [Accessed Nov. 2013].

[35] Slomanson WR. 2010. Fundamental Perspectives on International Law, sixth edition. Wadsworth, Boston, USA. $772 \mathrm{pp}$.

[36] UNGA res44/225 (1989) and 46/215 (1991)

[37] UNGA. Sustainable fisheries, including through the 1995 Agreement for the Implementation of the Provisions of the United Nations Convention on the Law of the Sea of 10 December 1982 relating to the Conservation and Management of Straddling Fish Stocks and Highly Migratory Fish Stocks, and related instruments. Passed 2006, published 2007; resolution 61/105 §83(c).

[38] UNGA. Workshop to discuss implementation of paragraphs 80 and 83 to 87 of resolution $61 / 105$ and paragraphs 117 and 119 to 127 of resolution 64/72 on sustainable fisheries, addressing the impacts of bottom fishing on vulnerable marine ecosystems and the long-term sustainability of deep-sea fish stocks Letter dated 27 October 2011 from the Moderator of the Workshop to the President of the General Assembly. 2011.

A/66/566, §8.

[39] Gianni, M, Curri, DEJ, Fuller S, Speer L, Ardron J, Weeber B, Gibson M, Roberts G, Sack K, Owen S, Kavanagh A. Unfinished business: a review of the implementation of the provisions of UNGA

Unfinished business: a review of the implementation of the provisions of UNGA resolutions 61/105 and 64/72

related to the management of bottom fisheries in areas beyond national jurisdiction, Deep Sea Conservation Coalition, 2011.

[40] Weaver PPE, Benn A, Arana PM, Ardron JA, Bailey DM, Baker K, Billett DSM, Clark MR, Davies AJ, Durán Muñoz P, Fuller SD, Gianni M, Grehan AJ, Guinotte J, Kenny A, Koslow JA, Morato T, Penney AJ, Perez JAA, Priede IG, Rogers AD, Santos RS, Watling L. The impact of deep-sea fisheries and implementation of the UNGA Resolutions 61/105 and 64/72. Report of an international scientific workshop, National Oceanography Centre, Southampton, 2011. <http://hdl.handle.net/10013/epic.37995> [Accessed Nov 2013].

[41] Penney AJ, Parker SJ, Brown JH. 2009. Protection measures implemented by New Zealand for vulnerable marine ecosystems in the South Pacific Ocean. Marine Ecological Progress Series, 397: 341-354.

<http://www.int-res.com/articles/theme/m397p341.pdf> [Accessed Nov 2013].

[42] Hauck H. Rethinking small-scale fisheries compliance. Marine Policy 2008; 32(4):635-642.

[43] Rieser A, Wattling L, Guinotte J. 2012. Trawl fisheries, catch shares and the protection of benthic marine ecosystems: Has ownership generated incentives for seafloor stewardship? Marine Policy, 40:75-83.

[44] Gianni M \& Bos OG. Protecting ecologically and biologically significant areas (EBSAs): Lessons learned from the implementation of UN resolutions to protect deep-sea biodiversity. IMARES - Institute for Marine Resources \& Ecosystem Studies, 2012; C061/12.

[45] UNGA. Oceans and the Law of the Sea. 2004 (published 2005); A/RES/59/24 §73. 
[46] UNGA. Report of the Ad Hoc Open-ended Informal Working Group to study issues relating to the conservation and sustainable use of marine biological diversity beyond areas of national jurisdiction. 2006; $\mathrm{A} / 61 / 65 ; \S 9$.

[47] UN, 2012, §13. Report of the Ad Hoc Open-ended Informal Working Group to study issues relating to the conservation and sustainable use of marine biological diversity beyond areas of national jurisdiction and CoChairs' summary of discussions. A/67/95.

[48] United Nations Conference on Environment and Development (UNCED). Plan of Implementation of the World Summit on Sustainable Development, 2002; §32(c).

<http://www.un.org/esa/sustdev/documents/WSSD_POI_PD/English/WSSD_Planlmpl.pdf> [Accessed Nov. 2013].

[49] UNGA. The Future We Want. 2012; A/RES/66/288,§177.

[50] Kim J-E. 2012. The incongruity between the ecosystem approach to high seas marine protected areas and the existing high seas conservation regime. Aegean Rev Law Sea 2013; 2(1-2):1-36.

[51] Gjerde KM et al. 2008. Regulatory and Governance Gaps in the International Regime for the Conservation and Sustainable Use of Marine Biodiversity in Areas beyond National Jurisdiction. IUCN, Gland, Switzerland.

[52] ISA. Decision of the Council of the International Seabed Authority relating to amendments to the Regulations on Prospecting and Exploration for Polymetallic Nodules in the Area and related matters. 2013; ISBA/19/C/17;§V.31.6.

[53] ISA. Decision of the Council relating to an environmental management plan for the Clarion-Clipperton Zone. 2012. ISBA/18C/22. <http://www.isa.org.jm/files/documents/EN/18Sess/Council/ISBA-18C-22.pd>f [Accessed Oct. 2013].

[54] MARPOL, Annexes 1, 2, 4, 5, 6.

[55] IMO. Revised guidelines for the identification and designation of Particularly Sensitive Sea Areas (PSSAs), 2005; A.982(24).

[56] Safety of Life at Sea Convention (SOLAS), 1974; V.10 and the General Provisions on Ships' Routing.

[57] CCAMLR. General framework for the establishment of CCAMLR Marine Protected Areas, 2011; Conservation Measure 91-04.

[58] The Antarctic Treaty system. Protocol on environmental protection, 1991; Recommendation XVI-10, Annex $\mathrm{V}$.

[59] Barr LM, Possingham HP. Are outcomes matching policy commitments in Australian marine conservation planning? Marine Policy 2013, 42:39-48

[60] Kearney R. Australia's Out-Dated Concern over Fishing Threatens Wise Marine Conservation and Ecologically Sustainable Seafood Supply. Open Journal of Marine Science 2013, 3(2): 55-61.

[61] Pressey B. Australia's new marine protected areas: why they won't work. The Conversation, 17 January 2013. < http://theconversation.edu.au/australias-new-marine-protected-areas-why-they-wont-work-11469> [Accessed Dec 2013].(Note: A paper on this topic is forthcoming.)

[62] CBD 2008. Decision IX/20, annex 2.

[63] Huntington BE. Confronting publication bias in marine reserve meta-analyses. Frontiers in Ecology and the Environment 2011;9:375-376.

[64] Margules CR \& Pressey RL. Systematic conservation planning. Nature 2000; 405, 243-253.

[65] Langhammer PF, Bakarr MI, Bennun LA, Brooks TM, Clay RP, Darwall W, De Silva N, Edgar GJ, Eken G, Fishpool LDC, Fonseca GAB da, Foster MN, Knox DH, Matiku P, Radford EA, Rodrigues AS., Salaman P, Sechrest W, \& Tordoff AW. Identification and Gap Analysis of Key Biodiversity Areas: Targets for Comprehensive Protected Area Systems. Gland, Switzerland: IUCN 2007.

[66] Pressey RL \& Taffs KH. Scheduling conservation action in production landscapes: priority areas in western New South Wales defined by irreplaceability and vulnerability to vegetation loss. Biological Conservation 2001; 100,355-376.

[67] CBD. Ecosystem approach. 2000; Decision V/6.

[68] Fisheries Jurisdiction case (United Kingdom v Iceland), ICJ Reports 1973,3.

[69] Warner R, Gjerde K, \& Freestone D. Regional institutions and processes: progress in fragmented frameworks. Garcia SM, Rice J \& Charles T (eds). Governance for Marine Fisheries and Biodiversity Conservation, Interaction and Co-evolution. Wiley Blackwell Publishers in press [2014]; ch. 14.

[70] CBD, Report of Joint Expert Meeting on Addressing Biodiversity Concerns in Sustainable Fishery, UNEP/CBD/SBSTTA/16/INF/13, 2012, paragraph 4.

[71] CBD, Report of Joint Expert Meeting on Addressing Biodiversity Concerns in Sustainable Fishery, UNEP/CBD/SBSTTA/16/INF/13, 2012, Annex III, paragraphs 8-9. 
[72] CBD, Report of Joint Expert Meeting on Addressing Biodiversity Concerns in Sustainable Fishery, UNEP/CBD/SBSTTA/16/INF/13, 2012, Annex III, paragraph 8.

[73] CBD, Report of Joint Expert Meeting on Addressing Biodiversity Concerns in Sustainable Fishery, UNEP/CBD/SBSTTA/16/INF/13, 2012, Annex III, paragraph 9.

[74] Berkes F, Hughes TP, Steneck RS, Wilson JA, Bellwood DR, Crona B, Folke C, Gunderson LH, Leslie HM, Norberg J, Nyström M, Olsson P, Österblom H, Scheffer M, Worm B. Globalization, roving bandits, and marine resources. Science 2006, 311(5767):1557-1558.

[75] Swedish FAO Committee. Roving Bandits in Modern Fisheries. Publication series 5, 2009. <http://www.government.se/content/1/c6/12/11/81/d99cc30a.pdf> [Accessed Oct. 2013].

[76] CBD, Report of Joint Expert Meeting on Addressing Biodiversity Concerns in Sustainable Fishery, UNEP/CBD/SBSTTA/16/INF/13, 2012, Annex III, paragraphs 39-43. 